\title{
TYMPANOPLASTY: BLOOD-SOAKED GELFOAM VERSES ANTIBIOTIC-SOAKED GELFOAM AS EAR CANAL PACKING
}

Gaurav Khandelwal ${ }^{1}$

${ }^{1}$ Assistant Professor, Department of ENT, F. H. Medical College.

\section{ABSTRACT}

\section{OBJECTIVE}

The objective of our study is to compare the result of blood-soaked gelfoam with antibiotic-soaked gelfoam on graft stickiness in tympanoplasty.

\section{STUDY DESIGN}

A prospective randomized case control study was performed to compare the outcome of our patient who underwent surgery by using blood-soaked gelfoam and gelfoam soaked in antibiotic ear drops.

\section{METHOD}

Patients having central perforation were divided into two groups using random tables. After complete investigations, they underwent tympanoplasty. Temporalis fascia graft was used and placed by underlay technique. Middle ear was not packed with gelfoam. After placing the graft, gelfoam was placed around the freshened perforation margins to hold the graft. These gelfoa m pieces were either antibiotic soaked or fresh blood soaked.

\section{RESULT}

A total of 55 patients were enrolled in the study. Graft stickiness at 4 week was $93.10 \%$ for blood-soaked group, whereas it was $84.81 \%$ for antibiotic-soaked group. Total success rate at 6 months was $94.5 \%$.

\section{CONCLUSION}

Blood-soaked gelfoam packing of external meatus around the perforation margins gives good results in tympanoplasty.

\section{KEYWORDS}

Tympanoplasty, Gelfoam in Tympanoplasty, Blood-Soaked Gelfoams.

HOW TO CITE THIS ARTICLE: Khandelwal G. Tympanoplasty: blood-soaked gelfoam verses antibiotic-soaked gelfoam as ear canal packing. J. Evolution Med. Dent. Sci. 2016;5(53):3560-3562, DOI: 10.14260/jemds/2016/820

\section{INTRODUCTION}

Tympanoplasty was first described by Wullstein 1 in 1952 who used a split thickness skin graft followed by Zollner who used the same graft. Since then, tympanoplasty gradually evolved. It was Heerman ${ }^{2}$ in 1958 who used temporalis fascia graft. In the year 1960, Shea using vein graft described the underlay technique. ${ }^{3}$ Gelatin sponge also known as gelfoam has been in use in ear surgeries since 1945. The graft used in tympanoplasty is usually placed as a sandwich of gelfoam. 4

Various techniques have been attempted in order to achieve better results with improved hearing. These include the overlay tympanoplasty, 5 the underlay tympanoplasty, ${ }^{6}$ over underlay tympanoplasty, 7 Gelfilm sandwich tympanoplasty, ${ }^{4}$ Crown cork tympanoplasty, ${ }^{8}$ swinging door tympanoplasty, ${ }^{9}$ laser assisted spot welding techniques, ${ }^{10}$ and microclip techniques ${ }^{11}$ and others like the fascial pegging, ${ }^{12}$ annular wedge tympanoplasty, ${ }^{13}$ loop tympanoplasty ${ }^{14}$ which are but modifications of the basic technique. Office tympanoplasty techniques like the paper patching, lobule fat

Financial or Other, Competing Interest: None.

Submission 23-05-2016, Peer Review 18-06-2016,

Acceptance 23-06-2016, Published 04-07-2016.

Corresponding Author:

Dr. Gaurav Khandelwal,

Assistant Professor,

Department of ENT

F. H. Medical College,

Tundla, Firozabad.

E-mail: gaurav4u1977@gmail.com

DOI: $10.14260 /$ jemds $/ 2016 / 820$ graft, and the self-stabilizing tympanic membrane patchers. ${ }^{15}$ Here we describe a method of using fresh blood-soaked gelfoam in underlay tympanoplasty wherein we do not pack the middle ear cavity with gelfoam.

\section{MATERIALS AND METHOD}

A prospective study was performed to compare the outcome of our patient who undergone surgery by using blood-soaked gelfoam and gelfoam soaked in antibiotic ear drops.

\section{Inclusion Criteria Included}

Age between 16-50 years, central perforation, dry ear, and middle ear mucosa healthy.

\section{Exclusion Criteria}

Cholesteatoma, granulations in middle ear, active disease with purulence, marginal perforation, severe to profound hearing loss, complicated chronic suppurative otitis media, diabetes mellitus, hypertensives and patients who were on oral anticoagulants. Patients were selected for tympanoplasty from a tertiary health care outpatient department. Preoperatively, a detailed history was taken and examination done. The size and site of perforation was noted. Pure tone audiometry was done in all cases. All the ears were made dry before operating. A total of 55 patients were included in the study. The cases allotted were divided in two groups using random tables.

Patients underwent tympanoplasty by underlay technique via postaural approach under local anaesthesia. Margins of 
perforation were freshened and under surface of tympanic membrane remnant were scrapped to make it raw. No gelfoam was placed in the middle ear. The graft was placed medial to the handle of malleus. Gelfoam was placed along the remnant of tympanic membrane and the graft. In the group where blood-soaked gelfoam were used, fresh blood was taken by venepuncture from cubital vein to soak the gelfoam pieces. In study of antibiotic-soaked gelfoam, we first cleaned the surgical site by the dry gelfoam to remove the local blood from the site and antibiotic (Ciprofloxacin) soaked gelfoam placed.

Patients were examined at 2 weeks, 4 weeks, and at 6 months. Gelfoam was cleaned at $4^{\text {th }}$ week. Graft was assessed to being stuck all around the margins of perforation or have fallen in any of the quadrants. Success of grafting was determined at 6 months. Repeat audiogram was done at 6 months to note the hearing improvement.

\section{RESULTS}

Fifty five patients were enrolled in the study, out of which 26 were in antibiotic-soaked group and 29 in blood-soaked group. At 4 weeks, total graft displacement was in 6 patients. The distribution among both groups is given in table 1. Graft stickiness at 4 week was $93.10 \%$ for blood-soaked group whereas it was $84.81 \%$ for antibiotic-soaked group. The site of displacement was also noted and tabulated in table 2 . When compared statistically, using chi-square test, there was significant difference between the two groups for graft stickiness (Table 1).

These patients were followed for a total of six months. Three out of six displacements healed by themselves (Table 3). There were no failures in remaining patients. So, the total failure of grafting was only in three patients (Success rate of 94.5\%).

Hearing improved in all the cases having no residual perforations. Out of 52 healed perforations, 49 had improvement with air-bone gap less than $20 \mathrm{~dB}$ and rest had air-bone gap between 20-30 dB.

\begin{tabular}{|c|c|c|}
\hline & $\begin{array}{c}\text { Blood-Soaked } \\
\text { Gelfoam }\end{array}$ & $\begin{array}{c}\text { Antibiotic-Soaked } \\
\text { Gelfoam }\end{array}$ \\
\hline Success & $27(25.84)[0.05]$ & $22(23.16)[0.06]$ \\
\hline Failure & $2(3.16)[0.43]$ & $4(2.84)[0.48]$ \\
\hline Total & $\mathbf{2 9}$ & $\mathbf{2 6}$ \\
\hline \multicolumn{2}{|c|}{ Table 1: Graft Stickiness at 4th Week } \\
\hline
\end{tabular}
cell]

(The expected cell total), [The chi-square statistics for each

The chi-square statistics $1.0163, \mathrm{p}$ value is 0.03134 . The result is significant at $\mathrm{p}<0.05$.

\begin{tabular}{|l|c|c|}
\hline & Category & Site of Graft Displacement \\
\hline 1 & Blood Soaked & Anterior Displaced \\
\hline 2 & Antibiotic Soaked & Anterior Displaced \\
\hline 3 & Antibiotic Soaked & Anterior Displaced \\
\hline 4 & Antibiotic Soaked & Posterior Displaced \\
\hline 5 & Blood Soaked & Anterior Displaced \\
\hline 6 & Antibiotic Soaked & Anterior Displaced \\
\hline \multicolumn{2}{|c|}{ Table 2: Failure Site in Failed Cases } \\
\hline
\end{tabular}

\begin{tabular}{|l|c|c|}
\hline & Category & At 6 Month \\
\hline 1 & Blood Soaked & Perforation Healed \\
\hline 2 & Antibiotic Soaked & Residual Perforation \\
\hline 3 & Antibiotic Soaked & Residual Perforation \\
\hline 4 & Antibiotic Soaked & Residual Perforation \\
\hline 5 & Blood Soaked & Perforation Healed \\
\hline 6 & Antibiotic Soaked & Perforation Healed \\
\hline \multicolumn{3}{|c|}{ Table 3: Failure Cases at 6 Month } \\
\hline
\end{tabular}

\section{DISCUSSION}

Tympanoplasty is world over accepted to give 93-97\% results ${ }^{16}$ in terms of perforation closure. Various grafts have been used like split thickness skin graft, vein graft, temporalis fascial graft, perichondrial graft, and perichondrium cartilage composite graft. The most commonly used are the latter three. We here used temporalis fascia and overall success rate was 94.5\%, which is well accepted.

Many different materials have been placed in the middle ear in an attempt to prevent formation of adhesions and fibrous tissue including absorbable gelatin sponge (Gelfoam), hyaluronic acid, Silastic ${ }^{\mathrm{TM}}$, and Teflon ${ }^{\mathrm{TM}}$. However, none of the currently available materials is ideal and many ears develop problems with fibrosis, adhesions, and neo-osteogenesis despite the use of such materials. ${ }^{17,18}$ So, we decided not to use gelfoam in the middle ear and yet the success rates of graft uptake $(94.5 \%)$ in this study are comparable with acceptable results worldwide (93-97\%). ${ }^{16}$

We used freshly taken blood and soaked the gelfoam with it. These were placed over the graft and at the perforation margins. The hypothesis behind it was that the blood would clot, which will in turn provide a provisional matrix of fibrin, fibronectin, von Willebrand factor, and thrombospondin 19,20,21, which facilitates the early migration of cells into the wound environment, 22 stimulates fibroblast proliferation (via thrombin), and shield mitogenic and chemotactic factors from inhibitors. ${ }^{23}$ Additional activities of platelet are mediated by the release of an array of biologically active substances that stimulate the synthesis of extracellular matrix component and consequently initiate the subsequent phases of repair and also promote cell migration and in growth to the site.24 The fibrin would also act as tissue glue and would prevent graft falling in the middle ear. Autofibrin glue has been found to improve the results in tympanoplasty. ${ }^{25}$

In early postoperative period, 5 out of 6 displacements were in the anterior segment. This is because of the negative pressure of the Eustachian tube. Chances of failure are very high in anterior-superior quadrant since the graft may fall around the Eustachian tube orifice leading to the medialization of graft and blocking the Eustachian tube. ${ }^{26}$, but when followed up, 3 out of 6 perforations healed. This indicated that once healing process starts small residual perforations may heal by themselves.

\section{CONCLUSION}

Blood-soaked gelfoam packing of external meatus around the perforation margins gives good results in graft uptake (93.1\%) and may obviate the requirement of middle ear gelfoam placement. 


\section{REFERENCES}

1. Wullstein $\mathrm{H}$. Theory and practice of tympanoplasty. Laryngoscope 1956;66(8):1076-93.

2. Goodhill V, Harris I, Brockman SJ. Tympanoplasty with perichondrial graft. A preliminary report. Arch Otolaryngol 1964;79:131-7.

3. Shea JJ. Vein graft closure of eardrum perforations. Arch Otolaryngol 1960;72(4):445-7.

4. Karlan MS. Gelatin film sandwich in tympanoplasty. Otolaryngol Head Neck Surg 1979;87(1): 84-6.

5. House WF. Myringoplasty. AMA Arch Otolaryngol 1960;71(3):399-404.

6. Shea JJ. Jr Vein graft closure of eardrum perforations. J Laryngol Otol 1960;74:358-62.

7. Kartush JM, Michaelides EM, Becvarovski Z, et al. Overunder tympanoplasty. Laryngoscope 2002;112(5):802-7.

8. Hartwein J, Leuwer RM, Kehrl W. The total reconstruction of the tympanic membrane by the 'Crown cork' technique. Am J Otolaryngol 1992;13(3):172-5.

9. Schwaber MK. Postauricular under surface tympanic membrane grafting: some modifications of the swinging door technique. Otolaryngol Head Neck Surg 1986;95(2):182-7.

10. Escudero LH, Castro AO, Drumond M, et al. Argon laser in human tympanoplasty. Arch Otolaryngol 1979;105(5):252-3.

11. Williams JD. Microclip application in tympanoplasty. Ann Otol Rhinol Laryngol 1977;86(2):223-6.

12. Goodman WS, Wallace IR. Tympanoplasty- 25 years later. J Otolaryngol 1980;9(2):155-64.

13. Albera R, Ferrero V, Canale G. Annular wedge tympanoplasty: a variation of overlay myringoplasty. Acta Otorhinolaryngol Ital 1997;17(1):15-21.

14. Lee HY, Auo HJ, Kang JM. Loop overlay tympanoplasty for anterior or subtotal perforations. Auris Nasus Larynx 2010;37(2):162-6.

15. Kartush JM. TMPatcher: a new device to close tympanic membrane perforations in an office setting. Am J Otol 2000;21(5):615-20.
16. Sismanis AA. Tympanoplasty: tympanic membrane repair. In: Glasscock-Shambaugh surgery of the ear. $6^{\text {th }}$ edn. Shelton: People's medical publishing house 2008:465-88

17. Hellström S, Salén B, Stenfors LE. Absorbable gelatin sponge (gelfoam) in otosurgery: one cause of undesirable postoperative results? Acta Otolaryngol 1983;96(34):269-75.

18. Browning GG, Merchant SN, Kelly GD, et al. Chronic otitis media. In: Scott-Brown's otorhinolaryngology. $7^{\text {th }}$ edn. Vol. 3. London: Hodder Arnold 2008:3395-445.

19. Gailit JG, Clark RAF. Wound repair in the context of extracellular matrix. Current Opinion in Cell Biology 1994;6(5):717-25.

20. Thomas DW, O'Neil ID, Harding KG, et al. Cutaneous wound healing: a current perspective. Journal of Oral and Maxillofacial Surgery 1995;53(4):442-7.

21. Yamada KM, Clark RAF. Provisional matrix. In: Clark RAF ed. The molecular and cellular biology of wound repair. $2^{\text {nd }}$ edn. London: Plenum Press 1996:51-94.

22. Lanir N, Ciano PS, van de Water L, et al. Macrophage migration in fibrin gel matrices. II. Effects of clotting factor XIII, fibronectin and glycosaminoglycan contents on cell migration. Journal of Immunology 1998;140(7):2340-9.

23. Koopmann CF. Cutaneous wound healing: an overview. Otolaryngologic Clinics of North America 1995;28(5):835-45.

24. Ginsberg M. Role of platelets in inflammation and rheumatic disease. Advances in Inflammation Research 1981;2:53-5.

25. Shatkovskaya NY, Soushko YA, Veremeyenko KN, et al. Autofibrin glue compound and its utilization during reconstructive operations on the ear. Rev Laryngol Otol Rhinol 1999;120(1):53-6.

26. Schuknecht HF, Kerr AG. Pathology of Eustachian tube. Arch Otolaryngol 1967;86(5):497-502. 